\title{
Hypovitaminosis $\mathrm{C}$ and vitamin $\mathrm{C}$ deficiency in critically ill patients despite recommended enteral and parenteral intakes
}

Anitra C. Carr ${ }^{1 *}$, Patrice C. Rosengrave ${ }^{1}$, Simone Bayer ${ }^{1}$, Steve Chambers ${ }^{1}$, Jan Mehrtens ${ }^{2}$ and Geoff M. Shaw ${ }^{2}$

\begin{abstract}
Background: Vitamin C is an essential water-soluble nutrient which cannot be synthesised or stored by humans. It is a potent antioxidant with anti-inflammatory and immune-supportive roles. Previous research has indicated that vitamin C levels are depleted in critically ill patients. In this study we have assessed plasma vitamin C concentrations in critically ill patients relative to infection status (septic shock or non-septic) and level of inflammation (C-reactive protein concentrations). Vitamin C status was also assessed relative to daily enteral and parenteral intakes to determine if standard intensive care unit (ICU) nutritional support is adequate to meet the vitamin C needs of critically ill patients.
\end{abstract}

Methods: Forty-four critically ill patients (24 with septic shock, 17 non-septic, 3 uncategorised) were recruited from the Christchurch Hospital Intensive Care Unit. We measured concentrations of plasma vitamin C and a proinflammatory biomarker (C-reactive protein) daily over 4 days and calculated patients' daily vitamin C intake from the enteral or total parenteral nutrition they received. We compared plasma vitamin C and C-reactive protein concentrations between septic shock and non-septic patients over 4 days using a mixed effects statistical model, and we compared the vitamin C status of the critically ill patients with known vitamin C bioavailability data using a four-parameter log-logistic response model.

Results: Overall, the critically ill patients exhibited hypovitaminosis $C$ (i.e., $<23 \mu \mathrm{mol} / \mathrm{L}$ ), with a mean plasma vitamin $\mathrm{C}$ concentration of $17.8 \pm 8.7 \mu \mathrm{mol} / \mathrm{L}$; of these, one-third had vitamin $C$ deficiency (i.e., $<11 \mu \mathrm{mol} / \mathrm{L}$ ). Patients with hypovitaminosis $C$ had elevated inflammation (C-reactive protein levels; $P<0.05$ ). The patients with septic shock had lower vitamin $C$ concentrations and higher $C$-reactive protein concentrations than the non-septic patients $(P<0.05)$. Nearly $40 \%$ of the septic shock patients were deficient in vitamin C, compared with $25 \%$ of the non-septic patients. These low vitamin C levels were apparent despite receiving recommended intakes via enteral and/or parenteral nutritional therapy (mean $125 \mathrm{mg} / \mathrm{d}$ ).

Conclusions: Critically ill patients have low vitamin C concentrations despite receiving standard ICU nutrition. Septic shock patients have significantly depleted vitamin C levels compared with non-septic patients, likely resulting from increased metabolism due to the enhanced inflammatory response observed in septic shock.

Keywords: Intensive care, Vitamin C, Hypovitaminosis C, Sepsis, Critical illness, C-reactive protein, Enteral nutrition, Parenteral nutrition, Septic shock

\footnotetext{
* Correspondence: anitra.carr@otago.ac.nz

'Department of Pathology, University of Otago, Christchurch, PO Box 4345,

Christchurch 8140, New Zealand

Full list of author information is available at the end of the article
} 


\section{Background}

Vitamin $C$ is an essential water-soluble nutrient which cannot be synthesised by humans, owing to loss of the terminal enzyme in the biosynthetic pathway [1]. The vitamin has numerous physiological roles in the body through acting as an electron donor. It is a potent antioxidant, protecting important biomolecules (proteins, lipids and DNA) from oxidation, thus preserving essential tissue structure and function [2]. Vitamin $\mathrm{C}$ also acts as an enzyme cofactor for a number of biosynthetic enzymes involved in hormone synthesis and generation of metabolic energy [3], as well as an ever-expanding family of gene-regulatory enzymes $[4,5]$. Recent research has indicated important roles for vitamin $C$ in the regulation of gene transcription via transcription factors and epigenetic modifying enzymes [4, 5]. Its function as a cofactor for the metalloenzymes which synthesise the vasopressors noradrenaline and vasopressin suggests an important role in critically ill patients, particularly those with sepsis and septic shock [6]. Several early studies have indicated that critically ill patients, including those with sepsis, exhibit very low circulating vitamin $\mathrm{C}$ levels compared with healthy control individuals $[7,8]$, and deficient levels correlated with multiple organ failure [9]. Owing to the pleiotropic functions of vitamin $\mathrm{C}$ in the body, depleted vitamin $\mathrm{C}$ status in critically ill patients may compromise their recovery.

Patients in the intensive care unit (ICU) routinely receive enteral nutrition and/or parenteral nutrition for those who cannot receive enteral nutrition or cannot receive it in sufficient amounts [10]. The route of feeding-enteral or parenteral-is determined by the presence or absence of a functioning intestine and the haemodynamic status of the patient [11]. Nutritional requirements are often tailored in the setting of fluid restriction and organ failure [11]. Nutrition therapy provides essential macronutrients and micronutrients, such as vitamins A, C and E, which are thought to help prevent oxidative stress and modulate immune responses [12]. Although total parenteral nutrition (TPN) typically comprises $100 \mathrm{mg} /$ day vitamin $\mathrm{C}$, one study has indicated that restoration of normal circulating vitamin $C$ levels in critically ill patients requires a 30 -fold higher intake [13]. This is likely due to the enhanced metabolic demands for vitamin $C$ in these patients owing to inflammatory and/or infectious processes.

However, whether critically ill patients are receiving adequate vitamin $\mathrm{C}$ intakes via standard ICU nutritional therapy to meet their enhanced needs remains largely underexplored. We therefore assessed the plasma vitamin $\mathrm{C}$ status of critically ill patients in intensive care and related this to infectious status (septic shock or non-septic), inflammation (C-reactive protein concentrations) and daily enteral and/or parenteral intakes.

\section{Methods}

We carried out an observational study with 44 critically ill patients recruited in the ICU of Christchurch Hospital, Christchurch, New Zealand (December 2015August 2016). All procedures involving human participants were approved by the Southern Health and Disability Ethics Committee (15/STH/36).

All patients aged $>18$ years admitted to the ICU were eligible, except those not expected to survive $72 \mathrm{~h}$ or when consent could not be obtained. Proxy consent was obtained from the treating physician in consultation with family members when patient consent was not possible. Consent was sought from patients as soon as they had sufficiently recovered. Only one patient withdrew consent; that patient's data was discarded. The final cohort comprised 44 patients: a septic shock group $(n=24)$, a non-septic group $(n=17)$ and three patients who could not be categorised on the basis of the clinical notes and therefore were not included in subgroup analysis. Inclusion in the septic shock group required meeting the following criteria: receiving $\geq 5 \mu \mathrm{g} /$ minute noradrenaline or adrenaline, receiving intravenous antimicrobial therapy specifically for infection, evidence of organ dysfunction (i.e., Sequential Organ Failure Assessment [SOFA] score $\geq 2$ for at least one of respiratory function [ratio of partial pressure of arterial oxygen and fraction of inspired oxygen $<300$ ], liver function [bilirubin $>$ $33 \mu \mathrm{mol} / \mathrm{L}$ ], coagulation [platelets $<100 \times 10^{3} / \mu \mathrm{L}$ ] and renal function [creatinine $>171 \mu \mathrm{mol} / \mathrm{L}$ or creatinine increase $>50 \%$ of baseline if chronic renal failure]). One patient entered the study with unusually high plasma vitamin $C$ concentrations $(>100 \mu \mathrm{mol} / \mathrm{L})$ and was classified as an outlier. This patient was excluded from all analyses involving vitamin $\mathrm{C}$ and has been presented separately as a case study.

Several ICU scoring systems were used at enrolment: the Simplified Acute Physiology Score II (SAPS II) [14] and the Acute Physiology and Chronic Health Evaluation (APACHE) II and III scores [15]. Organ failure was assessed using the SOFA score [16] daily for the duration of the study.

\section{Vitamin C and C-reactive protein analysis}

A blood sample (4-ml ethylenediaminetetraacetic acid tube) was collected from each patient through an already established arterial line at enrolment (baseline $=0 \mathrm{~h}$ ) and at 12, 24, 48, 72 and $96 \mathrm{~h}$. The blood was immediately placed on ice and processed for vitamin $\mathrm{C}$ analysis within $2 \mathrm{~h}$ of collection by centrifugation at $4{ }^{\circ} \mathrm{C}$ to separate plasma, and precipitation of proteins and stabilisation of vitamin $\mathrm{C}$ was carried out with perchloric acid and the metal chelator diethylenetriaminepentaacetic acid as described previously [17]. The acidified supernatants were stored at $-80{ }^{\circ} \mathrm{C}$ for batch analysis. 
Urine samples were collected from a subset of patients through an indwelling urinary catheter at times 0,12 , 24, 48, 72 and 96 h. Plasma and urine vitamin C concentrations were determined using reversed-phase high-performance liquid chromatography with electrochemical detection as described previously [17]. Half of each acidified sample was treated with the reducing agent tris(2-carboxyethyl)phosphine (TCEP) to determine the amount of dehydroascorbic acid present [18]. Treatment of the samples with the reducing agent TCEP showed no significant gain in vitamin $\mathrm{C}$ concentrations, other than two of the samples which exhibited haemolysis. Plasma C-reactive protein concentration was assessed by endpoint nephelometry, and urinary creatinine concentrations were determined by the classical Jaffe reaction at Canterbury Health Laboratories, an International Accreditation New Zealand laboratory.

\section{Patient vitamin C intake assessment}

The daily vitamin $C$ intake of the patients was determined from the volume of enteral nutrition or TPN administered to the patients. The enteral nutrition (Jevity, Glucerna, and Osmolite [Abbott Nutrition, Lake Bluff, IL, USA], Fresubin 1000 complete and Fresubin $^{\circ}$ Energy Fibre [Fresenius Kabi, Bad Homburg, Germany]) contained 100-110 $\mathrm{mg}$ vitamin $\mathrm{C} / \mathrm{L}$, and the TPN (Olimel $^{\circ}$ N9; Baxter, Old Toongabbie, Australia) contained $62.5 \mathrm{mg}$ vitamin C/L plus an additional $150 \mathrm{mg} / \mathrm{L}$ sodium ascorbate, which was included as a $\mathrm{pH}$ stabiliser (Baxter Healthcare, Christchurch, NZ), providing a total of $196 \mathrm{mg} / \mathrm{L}$ ascorbic acid (vitamin C).

\section{Statistical analysis}

Data are represented as mean and SD or box plots showing median values, 25th and 75th percentiles as boundaries, and whiskers as the range. To compare plasma and urinary vitamin $\mathrm{C}$, as well as C-reactive protein concentrations, in septic shock and non-septic patients over the study period, we performed linear mixed effects models (LMEMs) using the lme4 [19] and lmerTest [20] packages in $\mathrm{R}$ version 3.2.4 [21]. Patient identity was included in all models as a random variable to account for repeated measures of the same patient over the 4 days. The Satterthwaite method was used to calculate $P$ values from $t$ tests. We included an interaction effect in both models of day sampled $\times$ patient group (septic shock or non-septic). Post hoc analysis was conducted for each model using the multcomp package in R [22]. Model assumptions were verified. All effects were statistically significant at $\alpha=0.05$.

Using the pharmacokinetic data from the study by Levine et al. [23], whereby the steady-state plasma vitamin $\mathrm{C}$ concentrations for vitamin $\mathrm{C}$-deficient individuals were determined following vitamin $\mathrm{C}$ of doses of 30-
$1000 \mathrm{mg} /$ day, we constructed a dose-response model. Using this model we estimated plasma vitamin $\mathrm{C}$ concentrations for the critically ill patients in this study on the basis of the known daily enteral and/or parenteral nutritional intake they received. To do this we constructed a four-parameter log-logistic response model using the drc package in $\mathrm{R}[24]$ and the following function: $\quad((\mathrm{f}(\mathrm{x})=\mathrm{c}+\mid \operatorname{frac}\{\mathrm{d}-\mathrm{c}\}\{1+\exp (\mathrm{b}(\backslash \log (\mathrm{x})-\mid \log (\mathrm{e})))\})$. All model assumptions were met.

\section{Results}

\section{Patient characteristics}

During the study period, 44 patients (24 septic shock patients, 17 non-septic patients and 3 uncategorised) were recruited from the ICU. Demographic and clinical characteristics of the recruited patients are shown in Table 1. Of the participants, $61 \%$ were male, including $71 \%$ and $58 \%$ in the non-septic and septic shock groups, respectively. There were no statistically significant differences detected between the septic shock and non-septic patients in terms of demographic data and clinical characteristics. The non-septic group comprised primarily cardiac cases, whereas the sources of infection in the septic shock group were primarily abdominal and respiratory in origin. Severity of illness based on the SOFA, SAPS II and APACHE II scores were comparable between the groups at the time of enrolment.

Table 1 Participant characteristics

\begin{tabular}{|c|c|c|c|c|}
\hline Characteristic & $\begin{array}{l}\text { Total cohort } \\
(n=44)^{*}\end{array}$ & $\begin{array}{l}\text { Non-septic } \\
(n=17)\end{array}$ & $\begin{array}{l}\text { Septic shock } \\
(n=24)\end{array}$ & $P$ value $^{a}$ \\
\hline Gender, $\%$ male & 61 & 71 & 58 & \\
\hline Age, years & $64(14)$ & $64(11)$ & $64(15)$ & 0.3 \\
\hline Weight, kg & $78(20)$ & 87 (18) & $72(19)$ & 0.9 \\
\hline \multicolumn{5}{|l|}{ Baseline disease } \\
\hline Cardiac & & 12 & & \\
\hline Neurological & & 3 & & \\
\hline Trauma & & 1 & & \\
\hline Failed renal transplant & & 1 & & \\
\hline \multicolumn{5}{|l|}{ Source of sepsis } \\
\hline Abdominal & & & 13 & \\
\hline Respiratory & & & 8 & \\
\hline Skin/joint & & & 2 & \\
\hline Urinary & & & 1 & \\
\hline SAPS $\|$ & $45.8(14)$ & 46.5 (13) & $45.3(16)$ & 0.8 \\
\hline APACHE $\|$ & $20(6.4)$ & $21.4(7.0)$ & $19(5.9)$ & 0.3 \\
\hline SOFA & $8.2(3.6)$ & $9.4(3.5)$ & $7.6(3.2)$ & 0.8 \\
\hline
\end{tabular}

Abbreviations: SAPS Simplified Acute Physiology Score, APACHE Acute Physiology and Chronic Health Evaluation, SOFA Sequential Organ Failure Assessment

Data are presented as percentage or mean and SD where applicable ${ }^{*}$ Note that three patients could not be categorised as either non-septic or septic shock

aUnpaired Student's $t$ test for non-septic versus septic shock 
Plasma vitamin C status of critically ill patients

The baseline vitamin $\mathrm{C}$ status of the total cohort was $17.8 \pm 8.7 \mu \mathrm{mol} / \mathrm{L}$; of these, $68 \%$ were classified as hypovitaminosis $\mathrm{C}$ (i.e., $<23 \mu \mathrm{mol} / \mathrm{L}$ ), and $32 \%$ were deficient in vitamin $\mathrm{C}$ (i.e., $<11 \mu \mathrm{mol} / \mathrm{L}$ ). Overall, mean plasma vitamin $\mathrm{C}$ concentrations were significantly lower in septic shock patients $(15.3 \pm 7.9 \mu \mathrm{mol} / \mathrm{L})$ than in the nonseptic patients $\left(20.8 \pm 8.9 \mu \mathrm{mol} / \mathrm{L} ; \mathrm{LMEM}, F_{1,38.5}=5.1 ; P\right.$ $=0.03$ ) (Fig. 1a). Of the septic shock patients, $88 \%$ were in the hypovitaminosis C category, compared with $50 \%$ in the non-septic patients, and $38 \%$ of the septic shock patients were deficient in vitamin C, compared with $25 \%$ of the non-septic patients. There was no interaction

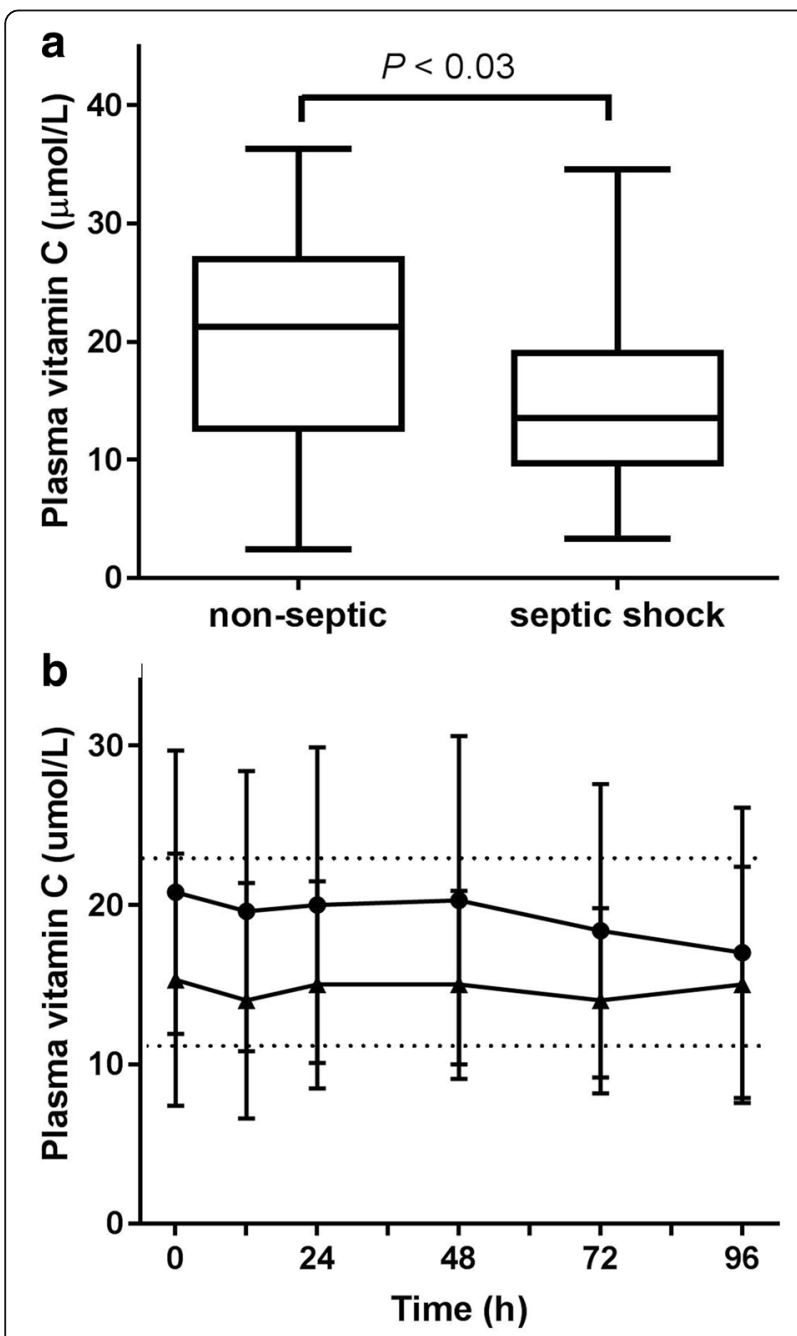

Fig. 1 Plasma vitamin C concentrations in critically ill patients. a Septic shock patients had significantly lower vitamin $C$ concentrations than non-septic patients ( $P<0.03$ using linear mixed effects model). Box plots show median with 25th and 75th percentiles as boundaries, and whiskers are the range. $\mathbf{b}$ Time course of plasma vitamin C concentrations in the non-septic group (filled circles) and the septic shock group (filled triangles). Data represent mean and SD. Dotted lines indicate the hypovitaminosis C cutoff $(23 \mu \mathrm{mol} / \mathrm{L})$ and vitamin $C$ deficiency cutoff $(11 \mu \mathrm{mol} / \mathrm{L})$ effect on plasma vitamin $\mathrm{C}$ levels between day sampled during the study and patient group (septic shock and non-septic; LMEM, $\mathrm{F}_{4,114.4}=1.1 ; P=0.4$ ) (Fig. $1 \mathrm{~b}$ ), suggesting that vitamin $C$ levels did not vary over the days sampled and between patient groups.

\section{C-reactive protein concentrations relative to plasma vitamin C}

C-reactive protein levels were dependent on the interaction effect between day sampled and patient group (LMEM, $\left.F_{4,115}=5.3, P=0.0006\right)$. At baseline (time = $0 \mathrm{~h}$ ), patients with septic shock had 2.4-fold higher $\mathrm{C}$ reactive protein concentrations $(254 \pm 121 \mathrm{mg} / \mathrm{L})$ than non-septic patients $(105 \pm 84 \mathrm{mg} / \mathrm{L}$; LMEM, $\mathrm{z}=4.4, P<$ $0.001)$ and remained higher than non-septic patients for the first $48 \mathrm{~h}$ (LMEM, $\mathrm{z}=5.6-3.9, \quad P<0.001-0.04$ ) (Fig. 2a). After this time, C-reactive protein levels were the same as those of non-septic patients. For non-septic patients, C-reactive protein levels were the lowest at baseline compared with the other time points sampled (LMEM, $\mathrm{z}=3.1-3.6, P=0.01-0.04)$. When baseline $\mathrm{C}$ reactive protein levels were divided around the hypovitaminosis C cutoff, there was a significant difference between the two groups $(P=0.05)$, with the mean $C$ reactive protein value for the hypovitaminosis $C$ group being $216 \pm 122 \mathrm{mg} / \mathrm{L}$ and that of the $>23 \mu \mathrm{mol} / \mathrm{L}$ group being $130 \pm 122 \mathrm{mg} / \mathrm{L}$ (Fig. 2b).

\section{Plasma vitamin C concentrations relative to intakes}

Over $80 \%$ of the critically ill patients received enteral and/or parenteral nutrition over the duration of the 4-day study period. The average daily intake of vitamin $\mathrm{C}$ for those who received enteral and/or parenteral nutrition was $125 \pm 88 \mathrm{mg} /$ day (with the maximum intake being $448 \mathrm{mg} /$ day). Of the total cohort, 64\% received enteral nutrition only (mean vitamin $C$ intake $102 \pm 54 \mathrm{mg} /$ day), $7 \%$ received total parenteral nutrition only (mean vitamin C intake $206 \pm 106 \mathrm{mg} /$ day) and 10\% received a combination of enteral and parenteral (mean vitamin C intake $195 \pm 144 \mathrm{mg} /$ day).

Using the pharmacokinetic data from the study by Levine et al. [23], we constructed a four-parameter loglogistic response model to predict the plasma vitamin $\mathrm{C}$ concentrations for the critically ill patients on the basis of their enteral and/or parenteral vitamin $C$ intakes. The predicted plasma concentrations, although variable, were significantly higher at all time points than the measured plasma concentrations $(P<0.0001$; Fig. 3$)$. On average, the measured plasma vitamin $C$ values were approximately one-third of the values predicted from intake.

There are a number of possible explanations for the discrepancy in predicted and measured vitamin $C$ concentrations, such as decreased absorption due to gastrointestinal dysfunction in the critically ill patients. However, the 


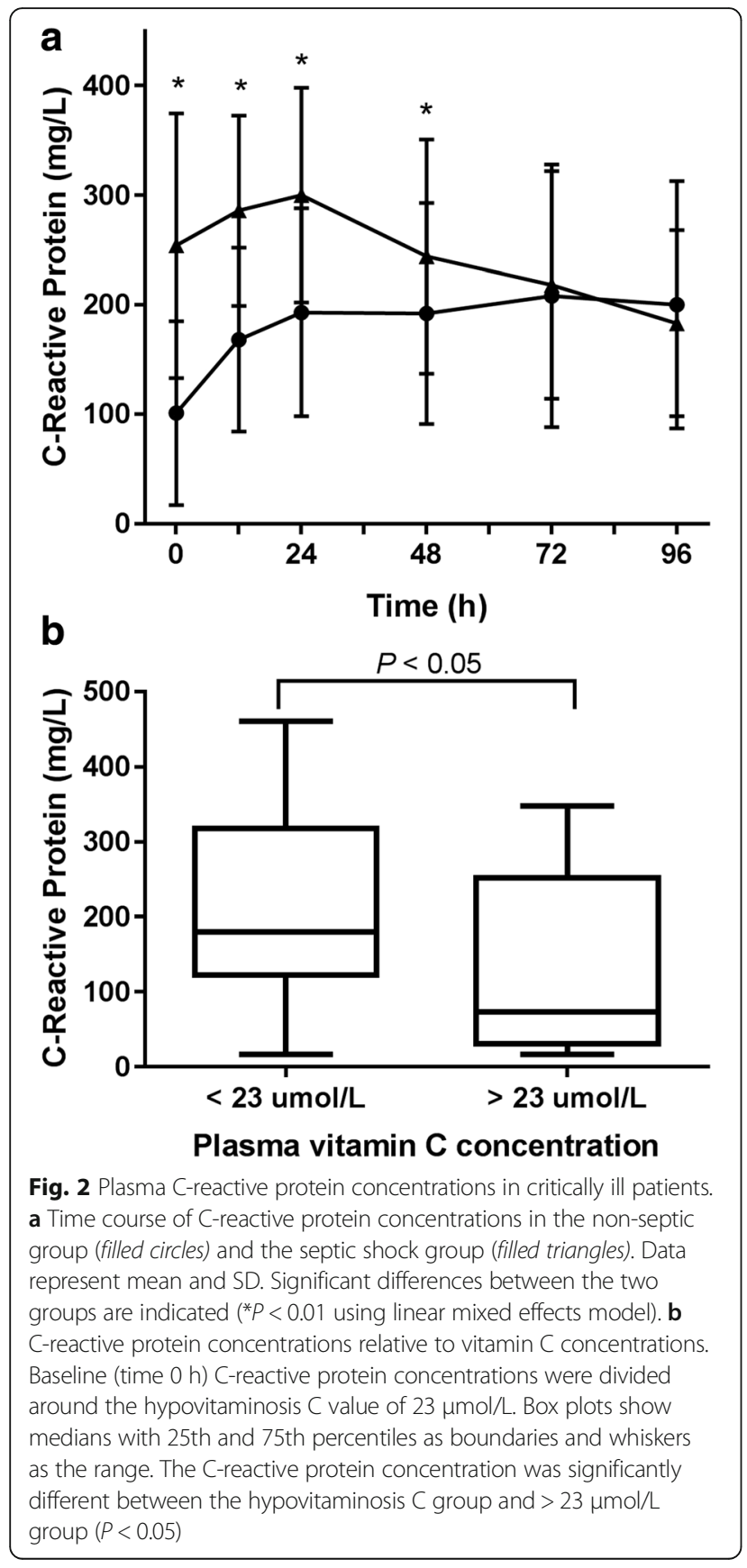

patients who were receiving TPN also exhibited hypovitaminosis $C$ (i.e., $16.6 \pm 7.5 \mu \mathrm{mol} / \mathrm{L}$ ). Another explanation for the difference between predicted and measured vitamin $\mathrm{C}$ concentrations is haemodilution due to increased volume of distribution of vitamin $C$ because of the relatively higher water content in critically ill patients after fluid resuscitation. When haemodilution was estimated by comparing the patients' haematocrit with genderspecific norms, this accounted for $25-34 \%$ of the difference (data not shown). Dialysis can also decrease plasma vitamin C levels by up to one-half; however, only five patients were

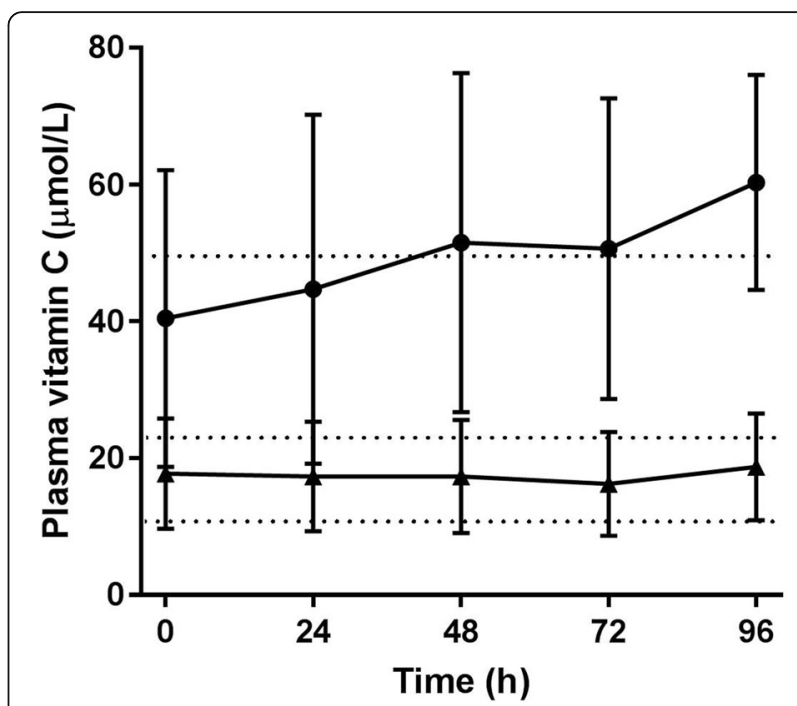

Fig. 3 Predicted compared with measured vitamin C concentrations in critically ill patients. Vitamin C concentrations predicted from enteral and/or parenteral administration (filled circles) were compared with measured plasma vitamin C concentrations (filled triangles). Predicted levels were obtained by fitting a four-parameter log-logistic response model to the pharmacokinetic data reported elsewhere [23]. Data represent mean and SD. All measured values were significantly lower than predicted values $(P<0.0001)$. Dotted lines indicate inadequate vitamin $C$ cutoff $(50 \mu \mathrm{mol} / \mathrm{L})$, hypovitaminosis $C$ cutoff $(23 \mu \mathrm{mol} / \mathrm{L})$ and vitamin $C$ deficiency cutoff $(11 \mu \mathrm{mol} / \mathrm{L})$

on dialysis during the study period (two non-septic and three septic shock patients), thus, cannot account for the low vitamin $\mathrm{C}$ concentrations in the other patients.

\section{Urinary excretion of vitamin C}

Enhanced urinary excretion of vitamin $\mathrm{C}$ due to glomerular hyperfiltration and/or dysfunctional tubular reabsorption could potentially result in depleted plasma levels. Therefore, we assessed urinary excretion of vitamin $C$ in a subset of the participants $(n=11$, comprising 6 male and 5 female, 7 septic shock and 3 non-septic). Urine samples were collected daily at the time of blood sampling. Baseline urinary vitamin $\mathrm{C}$ concentrations were $41 \pm 30 \mu \mathrm{mol} / \mathrm{L}$, which increased by up to twofold, depending on the time sampled (LMEM, $F_{1,39}=2.5, P=$ $0.05)$. These concentrations are lower than we have observed previously in healthy participants (baseline $154 \mu \mathrm{mol} / \mathrm{L}$ [25]). Urinary vitamin C concentrations were standardised to urinary creatinine, which decreased by up to half over the 4 days, from a baseline value of $10.4 \pm 2.9 \mathrm{mmol} / \mathrm{L}$ (LMEM, $\left.F_{1,38}=6.1, P<0.001\right)$. Thus, urinary vitamin $C$ excretion increased twofold over time relative to urinary creatinine, from a baseline ratio of $4.2 \pm 2.9$ (LMEM, $\left.F_{1,39}=2.5, P=0.005\right)$. Urinary output doubled over the study period from a baseline value of $1114 \pm 591 \mathrm{ml} /$ day $\quad\left(\mathrm{LMEM}, \quad F_{4,31}=2.7, \quad P=0.05\right)$. 
Although 24-h urine collections were not undertaken for vitamin $\mathrm{C}$ analysis, we estimated the total vitamin $\mathrm{C}$ excreted on the basis of urinary output and related this to the amount of vitamin $\mathrm{C}$ administered to the $11 \mathrm{pa}-$ tients in their enteral and parenteral nutrition. Over the study period the patients were administered, on average, 80-122 $\mathrm{mg} /$ day vitamin $\mathrm{C}$ and excreted, on average, 8-31 mg/day vitamin C. Overall, the patients excreted approximately $15-30 \%$ of their administered vitamin C dose over the duration of the study.

\section{Rapid vitamin C loss in a critically ill patient}

One patient entered the study with a very high plasma vitamin $\mathrm{C}$ concentration of $104 \mu \mathrm{mol} / \mathrm{L}$. The patient had been admitted to the ICU following a failed kidney transplant operation. On admission to the ICU the patient was commenced on continuous venovenous haemodiafiltration for acute renal failure. As shown in Fig. 4a, the patient's initially high vitamin $\mathrm{C}$ concentrations dropped to $44 \mu \mathrm{mol} / \mathrm{L}$ within $24 \mathrm{~h}$ and continued to decrease to hypovitaminosis $\mathrm{C}$ values over the next 3 days in the ICU. Figure $4 \mathrm{~b}$ shows increasing $\mathrm{C}$-reactive protein concentrations with decreasing vitamin $\mathrm{C}$. On day 4 plasma vitamin $\mathrm{C}$ had dropped into the hypovitaminosis $C$ range, and C-reactive protein levels had spiked above $100 \mathrm{mg} / \mathrm{L}$, which is consistent with infection. One week later, the patient became febrile and was diagnosed with ventilator-associated pneumonia (Staphylococcus aureus), multiple septic emboli in the lungs, and urinary infection (Escherichia coli), and the patient had wound dehiscence. The patient's condition deteriorated, with fast atrial fibrillation and increasing vasopressor requirements (noradrenaline and vasopressin), and the patient died 2 days later.

\section{Discussion}

Our study revealed that nearly $70 \%$ of critically ill patients had hypovitaminosis $\mathrm{C}$, including a high percentage with vitamin $\mathrm{C}$ deficiency (32\%), despite receiving standard ICU nutritional support. Patients with septic shock have further depletion of plasma vitamin C, with nearly $90 \%$ having hypovitaminosis $\mathrm{C}$ and $40 \%$ having vitamin $\mathrm{C}$ deficiency, likely owing to enhanced activation of inflammatory pathways in response to infection, as reflected by higher C-reactive protein levels in these patients. This level of deficiency is significantly greater than we have observed in a middleaged community-dwelling cohort $(n=369)$, which exhibited $<13 \%$ hypovitaminosis $\mathrm{C}$ and only $2.4 \%$ deficiency [26]. On average, the plasma vitamin C values of those receiving enteral and parenteral nutrition were approximately one-third the values predicted from intake, suggesting that recommended ICU intakes are not sufficient to meet the needs of critically ill
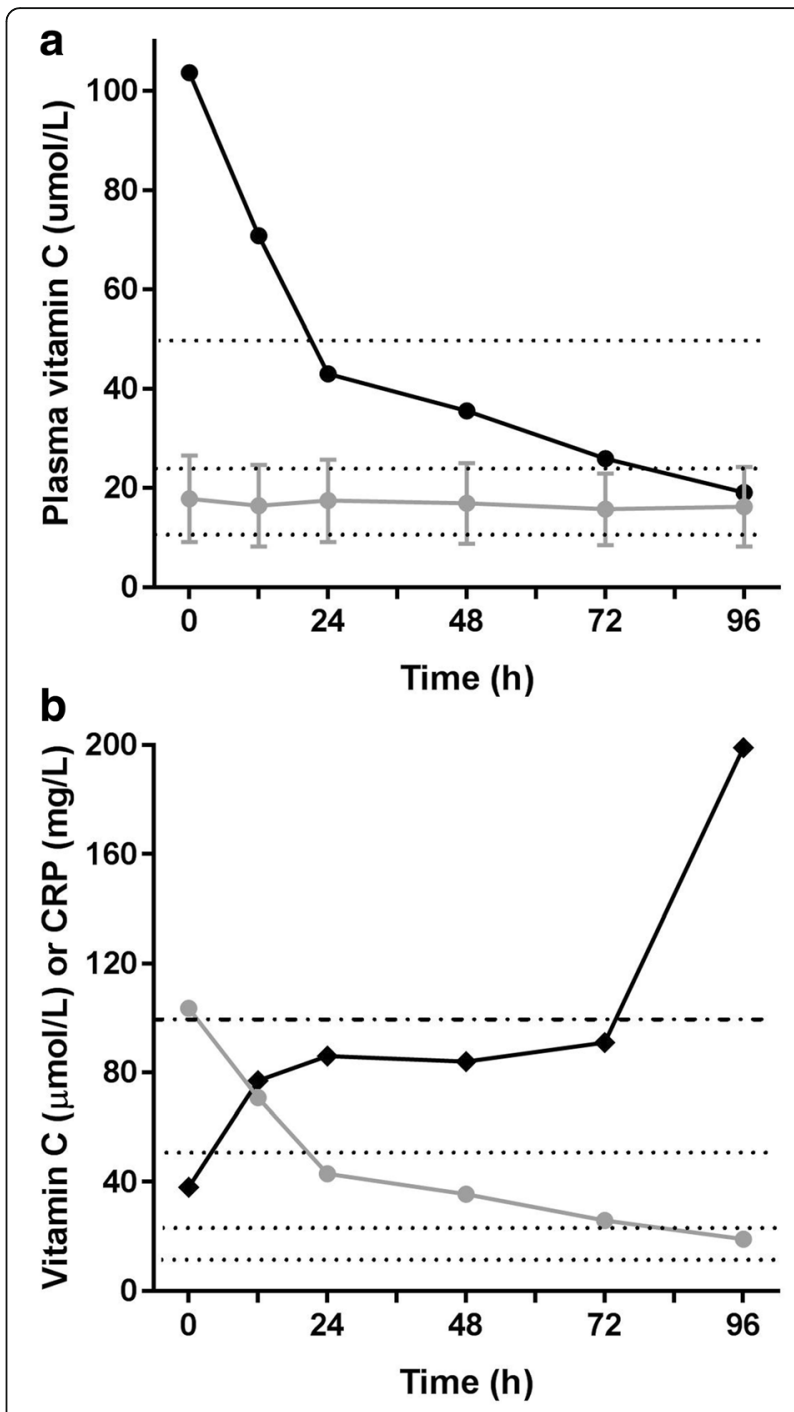

Fig. 4 Rapid loss of vitamin C in a critically ill patient. a The patient's vitamin C concentrations (black circles) were compared with the critically ill cohort (grey circles) over the 4-day study period. Data for the critically ill cohort represents mean and SD $(n=43)$. $\mathbf{b}$ Increasing C-reactive protein (CRP) concentrations (filled diamonds) relative to decreasing vitamin C concentrations (grey circles). Dotted lines indicate inadequate vitamin C cutoff ( $50 \mu \mathrm{mol} / \mathrm{L})$, hypovitaminosis $C$ cutoff $(23 \mu \mathrm{mol} / \mathrm{L})$ and vitamin $C$ deficiency cutoff $(11 \mu \mathrm{mol} / \mathrm{L})$; dashed line indicates infectious disease cutoff for CRP (100 mg/L)

patients. It should be noted that the pharmacokinetic data used to calculate the predicted vitamin $\mathrm{C}$ concentrations in our participants provide a conservative estimate, because all of the individuals in the pharmacokinetic study had vitamin $C$ deficiency prior to supplementation [23], so the difference between measured and predicted vitamin $\mathrm{C}$ concentrations in our participants may be even greater.

There are a number of possible explanations for the discrepancy in predicted and measured vitamin $\mathrm{C}$ concentrations. It is possible that enteral and parenteral 
preparations contain less vitamin $\mathrm{C}$ than stated, owing to the instability of the vitamin in the presence of oxygen, transition metal ions, ultraviolet light and higher temperatures [27, 28]. Furthermore, critically ill patients are at significant risk for gastrointestinal dysfunction and consequently poor absorption for those patients who receive enteral feeding [29]. Critically ill patients often exhibit gastrointestinal dysmotility, as well as feeding intolerance such as vomiting, aspiration of gastric contents, or high gastric residual volumes. Patients who are receiving sedatives and vasopressors are also at risk of feeding intolerance, and gastroparesis can be caused by pharmacologic agents that are frequently used in the ICU, such as opioids [30]. Additionally, gastric hypoperfusion in the context of shock or vasopressor use will contribute to poor nutritional uptake of essential vitamins [31]. Although early parenteral nutrition is discouraged in critically ill patients owing to increased risk of infection [31], parenteral feeding bypasses any issues with gastrointestinal dysfunction. Parenteral nutrition also bypasses the saturable intestinal uptake of orally administered vitamin $\mathrm{C}$ via sodium-dependent vitamin $\mathrm{C}$ transporter 1 (SVCT1) [23]. However, even the participants in our study receiving TPN, which provided an average of approximately $200 \mathrm{mg} /$ day vitamin C, exhibited hypovitaminosis $\mathrm{C}$.

Fluid resuscitation may haemodilute the plasma concentration of vitamin $C$. When we estimated haemodilution by comparing the patients' haematocrit with gender-specific norms, this accounted for only onefourth to one-third of the difference between the measured and predicted vitamin $C$ status. However, this correction is likely an overestimate because critically ill patients also have lower haemoglobin levels owing to inflammation-induced suppression of synthesis and blood sampling or loss. Vitamin $\mathrm{C}$ removal from the plasma via dialysis can also occur, and at least 50\% may be lost during continuous renal replacement therapy [32-34]. Our study cohort comprised only five patients who were on continuous venovenous haemodiafiltration for acute renal dysfunction whilst in the ICU. One of these patients was presented as a case study, highlighting a rapid and $>50 \%$ drop in vitamin $\mathrm{C}$ over the first $24 \mathrm{~h}$ in the ICU. Depleted plasma vitamin $\mathrm{C}$ status might also be due to glomerular hyperfiltration and/or dysfunctional tubular reabsorption of the vitamin via SVCT1 [35]. However, assessment of a subset of patients indicated a lower urinary concentration of vitamin $\mathrm{C}$ than we have previously observed in healthy individuals [25]. Furthermore, estimation of total vitamin $\mathrm{C}$ excretion based on urinary output provided values that were comparable to those of healthy individuals, who excrete $25 \%$ and $50 \%$ of a 100-mg dose (for males and females, respectively) $[23,36]$. Thus, these estimates suggest that our subset of critically ill patients with low plasma vitamin $\mathrm{C}$ concentrations were not excreting more vitamin $\mathrm{C}$ than healthy individuals.

Vitamin $\mathrm{C}$ acts as a potent antioxidant in vivo, scavenging a wide range of reactive oxygen and nitrogen species, and in the process becoming oxidised to dehydroascorbic acid [2]. The levels of dehydroascorbic acid detected in plasma are normally very low [7, 37]. Although some studies have shown higher levels of dehydroascorbic acid in samples collected from patients assumed to be under enhanced oxidative stress [38-40], we did not observe a significant increase in total vitamin $\mathrm{C}$ when our samples were treated with a reducing agent. This indicates that dehydroascorbic acid is not present in the circulation in significant amounts, even in critically ill patients when blood samples are collected and processed in a manner which minimises ex vivo oxidation of vitamin $\mathrm{C}$.

Several studies have shown subnormal vitamin C status in critically ill patients, and this correlated with the severity of the illness and with multiple organ failure $[7,9,13]$. It is likely that the low plasma vitamin $C$ levels in these patients are a marker for correspondingly low tissue status, because we and others have shown that tissue vitamin $\mathrm{C}$ status correlates closely with plasma vitamin $\mathrm{C}$ levels, both in humans and in animal models $[41,42]$. In the present study, we were able to compare patients with septic shock and non-septic patients and found that a greater proportion of patients with septic shock had hypovitaminosis $\mathrm{C}$ and vitamin $\mathrm{C}$ deficiency. This is likely due to enhanced metabolic turnover as a result of the elevated inflammatory response observed in septic shock. Indeed, the patients with septic shock in our cohort had higher $\mathrm{C}$-reactive protein levels than the non-septic patients for the first $48 \mathrm{~h}$ of the study. Creactive protein is an acute-phase protein synthesised by the liver during acute inflammation in response to infection, trauma, ischaemia and burns along with other inflammatory conditions, and it is often used as a biomarker of sepsis with high levels linked to higher incidences of organ failure and mortality [43]. In our study, significantly higher C-reactive protein levels were observed in patients with lower vitamin $\mathrm{C}$ status, which has been observed previously in hospitalised patients [44]. Furthermore, administration of vitamin $C$ to septic patients has been shown to lower $\mathrm{C}$-reactive protein and other pro-inflammatory biomarkers, as well as to decrease organ failure $[45,46]$.

The American Medical Association's Nutrition Advisory Board recommends an intake of $100 \mathrm{mg} /$ day vitamin $C$ via liquid nutrition [47]. However, hypovitaminosis $\mathrm{C}$ was not prevented in our patients with the use of standard enteral and/or parenteral nutrition, despite our TPN containing additional vitamin C 
(i.e., a total of nearly $200 \mathrm{mg} / \mathrm{L}$ ). These results agree with data reported by others who have shown that parenteral intakes of $\sim 300 \mathrm{mg} /$ day did not change their patients' plasma vitamin $\mathrm{C}$ concentrations [13, 27]. In comparison, intakes of $150-200 \mathrm{mg} /$ day will saturate the plasma of healthy individuals [23], although we and others have observed decreased response to supplementation in individuals with hypovitaminosis C $[48,49]$. Uncomplicated surgical patients require $>500 \mathrm{mg} /$ day of vitamin $\mathrm{C}$, with much higher doses required in surgical ICU patients [50]. Parentaeral administration of $\geq 1000 \mathrm{mg} /$ day vitamin $\mathrm{C}$ to critically ill patients was barely sufficient to raise plasma vitamin $C$ concentrations above hypovitaminosis C levels [13, 27]. Recent pharmacokinetic data in critically ill patients indicate that $\geq 2000 \mathrm{mg} /$ day is required to normalise plasma vitamin $C$ levels [51], and $3000 \mathrm{mg} /$ day has been shown to result in saturating levels (i.e., $68 \mu \mathrm{mol} / \mathrm{L}$ ), as evidenced by enhanced urinary excretion [13].

Vitamin $\mathrm{C}$ can be metabolised via dehydroascorbic acid to oxalate, which has the potential to form calcium oxalate crystals in individuals predisposed to renal stone formation. A few cases of acute oxalate nephropathy have been reported over the last 30 years in patients with impaired renal function following administration of high-gram doses of intravenous vitamin $C$ [52-54]. Administration of gram doses of vitamin $\mathrm{C}$ to individuals with normal renal function, however, results in $<0.2 \%$ oxalate excretion when samples are collected and stored in a manner which avoids artefactual oxidation [55]. Furthermore, no cases of oxalate nephropathy have been reported for low-gram doses of parenteral vitamin C.

\section{Conclusions}

We have shown that critically ill patients have very low plasma levels of vitamin $C$, with septic shock patients being particularly depleted, likely resulting from increased metabolism due to the enhanced inflammatory response observed in septic shock. Standard enteral and parenteral nutrition providing an average of 100 and $200 \mathrm{mg} /$ day vitamin C, respectively, is insufficient to meet the needs of critically ill patients. It is likely that vitamin $C$ doses of at least 2-3 g/ day are required for these patients. It is also important to note that administration of intravenous rather than oral vitamin $C$ may be required for optimal vitamin $C$ status in these patients because this route bypasses the saturable intestinal uptake of orally administered vitamin $C$ via SVCT1. Further studies assessing the optimal intake and the route of administration of vitamin $\mathrm{C}$ for critically ill patients in relation to physiological changes and clinically relevant outcomes are warranted.

\section{Abbreviations}

APACHE: Acute Physiology and Chronic Health Evaluation; CRP: C-reactive protein; ICU: Intensive care unit; LMEM: Linear mixed effects model; SAPS: Simplified Acute Physiology Score; SOFA: Sequential Organ Failure Assessment; SVCT: Sodium-dependent vitamin C transporter; TCEP: Tris(2carboxyethyl)phosphine; TPN: Total parenteral nutrition

\section{Acknowledgements}

We thank the study participants; Christchurch Hospital ICU research nurses Kim Parker, Anna Morris and Emmeline Minto for screening the patients; the Christchurch Hospital intensive care nurses for collecting blood samples; and Abel Ang for processing the samples.

\section{Funding}

ACC is a recipient of a Sir Charles Hercus Health Research Fellowship from the Health Research Council of New Zealand (16/037). PCR and SB were supported by a project grant from the Canterbury Medical Research Foundation (15/06, awarded to ACC) and a Carrell-Espiner Senior Research Fellowship from the University of Otago (awarded to ACC). GMS and SC were awarded a project grant from the Intensive Care Foundation. The funding bodies had no role in the design of the study; in the collection, analysis or interpretation of data; or in writing the manuscript.

\section{Availability of data and materials \\ Not applicable.}

\section{Authors' contributions}

ACC and GMS designed and coordinated the study. GMS and JM enrolled patients. JM coordinated sample collection. SB carried out vitamin C analyses. GMS and SC interpreted clinical data. ACC and PCR analysed data and wrote the paper. All authors read and approved the final manuscript.

\section{Authors' information}

Not applicable.

\section{Ethics approval and consent to participate}

All procedures involving human participants were approved by the Southern Health and Disability Ethics Committee (15/STH/36). Proxy consent was obtained from the treating physician in consultation with family members when patient consent was not possible. Consent from patients was sought as soon as they had sufficiently recovered.

\section{Consent for publication}

Not applicable.

\section{Competing interests}

The authors declare that they have no competing interests.

\section{Publisher's Note}

Springer Nature remains neutral with regard to jurisdictional claims in published maps and institutional affiliations.

\section{Author details \\ ${ }^{1}$ Department of Pathology, University of Otago, Christchurch, PO Box 4345, Christchurch 8140, New Zealand. '2Department of Intensive Care Medicine, Christchurch Hospital, Private Bag 4710, Christchurch 8140, New Zealand.}

Received: 4 September 2017 Accepted: 13 November 2017 Published online: 11 December 2017

\section{References}

1. Nishikimi M, Fukuyama R, Minoshima S, Shimizu N, Yagi K. Cloning and chromosomal mapping of the human nonfunctional gene for L-gulono- $\gamma^{-}$ lactone oxidase, the enzyme for L-ascorbic acid biosynthesis missing in man. J Biol Chem. 1994;269(18):13685-8.

2. Carr A, Frei B. Does vitamin C act as a pro-oxidant under physiological conditions? FASEB J. 1999;13(9):1007-24.

3. Englard S, Seifter S. The biochemical functions of ascorbic acid. Annu Rev Nutr. 1986;6:365-406. 
4. Kuiper C, Vissers MC. Ascorbate as a co-factor for Fe- and 2-oxoglutarate dependent dioxygenases: physiological activity in tumor growth and progression. Front Oncol. 2014;4:359.

5. Young Jl, Zuchner S, Wang G. Regulation of the epigenome by vitamin C. Annu Rev Nutr. 2015;35:545-64.

6. Carr AC, Shaw GM, Fowler AA, Natarajan R. Ascorbate-dependent vasopressor synthesis: a rationale for vitamin $C$ administration in severe sepsis and septic shock? Crit Care. 2015;19:e418.

7. Schorah CJ, Downing C, Piripitsi A, Gallivan L, Al-Hazaa AH, Sanderson MJ, Bodenham A. Total vitamin C, ascorbic acid, and dehydroascorbic acid concentrations in plasma of critically ill patients. Am J Clin Nutr. 1996;63(5): 760-5.

8. Bonham MJ, Abu-Zidan FM, Simovic MO, Sluis KB, Wilkinson A, Winterbourn CC, Windsor JA. Early ascorbic acid depletion is related to the severity of acute pancreatitis. Br J Surg. 1999:86(10):1296-301.

9. Borrelli E, Roux-Lombard P, Grau GE, Girardin E, Ricou B, Dayer J, Suter PM. Plasma concentrations of cytokines, their soluble receptors, and antioxidant vitamins can predict the development of multiple organ failure in patients at risk. Crit Care Med. 1996;24(3):392-7.

10. Yamazaki E, Horikawa M, Fukushima R. Vitamin C supplementation in patients receiving peripheral parenteral nutrition after gastrointestinal surgery. Nutrition. 2011;27(4):435-9.

11. Chan S, McCowen KC, Blackburn GL. Nutrition management in the ICU. Chest. 1999;115(5 Suppl):145S-8S.

12. Wintergerst ES, Maggini S, Hornig DH. Contribution of selected vitamins and trace elements to immune function. Ann Nutr Metab. 2007;51(4):301-23.

13. Long CL, Maull Kl, Krishnan RS, Laws HL, Geiger JW, Borghesi L, Franks W, Lawson TC, Sauberlich HE. Ascorbic acid dynamics in the seriously ill and injured. J Surg Res. 2003;109(2):144-8.

14. Le Gall JR, Lemeshow S, Saulnier F. A new Simplified Acute Physiology Score (SAPS II) based on a European/North American multicenter study. JAMA. 1993;270(24):2957-63.

15. Knaus WA, Draper EA, Wagner DP, Zimmerman JE. APACHE II: a severity of disease classification system. Crit Care Med. 1985;13(10):818-29.

16. Vincent JL, Moreno R, Takala J, Willatts S, De Mendonça A, Bruining H, Reinhart CK, Suter PM, Thijs LG. SOFA (Sepsis-related Organ Failure Assessment) score to describe organ dysfunction/failure. On behalf of the Working Group on Sepsis-Related Problems of the European Society of Intensive Care Medicine. Intensive Care Med. 1996;22(7):707-10.

17. Carr AC, Pullar JM, Moran S, Vissers MCM. Bioavailability of vitamin C from kiwifruit in non-smoking males: determination of 'healthy' and 'optimal' intakes. J Nutr Sci. 2012;1:e14.

18. Sato Y, Uchiki T, Iwama M, Kishimoto Y, Takahashi R, Ishigami A. Determination of dehydroascorbic acid in mouse tissues and plasma by using tris(2-carboxyethyl)phosphine hydrochloride as reductant in metaphosphoric acid/ethylenediaminetetraacetic acid solution. Biol Pharm Bull. 2010;33(3):364-9.

19. Bates D, Maechler M, Bolker B, Walker S, et al. 'Ime4': linear mixed-effects models using 'Eigen' and S4. R package version 1.1-8. 2015.

20. Kuznetsova A, Brockhoff P, Christensen R. ImerTest: tests in linear mixed effects models. R package version 2.0-30. 2016.

21. R Core Team. R: a language and environment for statistical computing Vienna: R Foundation for Statistical Computing; 2016

22. Hothorn T, Bretz F, Westfall P. Simultaneous inference in general parametric models. Biom J. 2008;50(3):346-63.

23. Levine M, Conry-Cantilena C, Wang Y, Welch RW, Washko PW, Dhariwal KR, Park JB, Lazarev A, Graumlich JF, King J, Cantilena LR. Vitamin C pharmacokinetics in healthy volunteers: evidence for a recommended dietary allowance. Proc Natl Acad Sci U S A. 1996;93(8):3704-9.

24. Ritz C, Baty F, Streibig JC, Gerhard D. Dose-response analysis using R. PLoS One. 2015;10(12):e0146021.

25. Carr AC, Bozonet SM, Vissers MC. A randomised cross-over pharmacokinetic bioavailability study of synthetic versus kiwifruit-derived vitamin C. Nutrients. 2013;5(11):4451-61.

26. Pearson JF, Pullar JM, Wilson R, Spittlehouse JK, Vissers MCM, Skidmore PML, Willis J, Cameron VA, Carr AC. Vitamin C status correlates with markers of metabolic and cognitive health in 50-year-olds: findings of the CHALICE cohort study. Nutrients. 2017;9(8):831.

27. Abrahamian V, Kaminski Jr MV, Santiago GC. Vitamin C supplementation of total parenteral nutrition formulas. JPEN J Parenter Enteral Nutr. 1983;7(5): 465-9.
28. Dupertuis YM, Morch A, Fathi M, Sierro C, Genton L, Kyle UG, Pichard C. Physical characteristics of total parenteral nutrition bags significantly affect the stability of vitamins C and B1: a controlled prospective study. JPEN J Parenter Enteral Nutr. 2002;26(5):310-6.

29. Fennessy GJ, Warrillow SJ. Gastrointestinal problems in intensive care. Anaesth Intensive Care Med. 2015;16(4):165-70.

30. Deane A, Chapman MJ, Fraser RJ, Bryant LK, Burgstad C, Nguyen NQ. Mechanisms underlying feed intolerance in the critically ill: implications for treatment. World J Gastroenterol. 2007;13(29):3909-17.

31. Rhodes A, Evans LE, Alhazzani W, Levy MM, Antonelli M, Ferrer R, Kumar A, Sevransky JE, Sprung CL, Nunnally ME, Rochwerg B, Rubenfeld GD, Angus DC, Annane D, Beale RJ, Bellinghan GJ, Bernard GR, Chiche JD, Coopersmith C, De Backer DP, French CJ, Fujishima S, Gerlach H, Hidalgo JL, Hollenberg SM, Jones AE, Karnad DR, Kleinpell RM, Koh Y, Lisboa TC, Machado FR, Marini JJ, Marshall JC, Mazuski JE, McIntyre LA, McLean AS, Mehta S, Moreno RP, Myburgh J, Navalesi P, Nishida O, Osborn TM, Perner A, Plunkett CM, Ranieri M, Schorr CA, Seckel MA, Seymour CW, Shieh L, Shukri KA, Simpson SQ, Singer M, Thompson BT, Townsend SR, Van der Poll T, Vincent JL, Wiersinga WJ, Zimmerman JL, Dellinger RP. Surviving Sepsis Campaign: International Guidelines for Management of Sepsis and Septic Shock: 2016. Crit Care Med. 2017:45(3):486-552.

32. Zhang K, Dong J, Cheng X, Bai W, Guo W, Wu L, Zuo L. Association between vitamin $C$ deficiency and dialysis modalities. Nephrology (Carlton). 2012;17(5):452-7.

33. Fehrman-Ekholm I, Lotsander A, Logan K, Dunge D, Odar-Cederlöf I, Kallner A. Concentrations of vitamin C, vitamin B12 and folic acid in patients treated with hemodialysis and on-line hemodiafiltration or hemofiltration. Scand J Urol Nephrol. 2008:42(1):74-80.

34. Story DA, Ronco C, Bellomo R. Trace element and vitamin concentrations and losses in critically ill patients treated with continuous venovenous hemofiltration. Crit Care Med. 1999;27(1):220-3.

35. Corpe CP, Tu H, Eck P, Wang J, Faulhaber-Walter R, Schnermann J, Margolis S, Padayatty S, Sun H, Wang Y, Nussbaum RL, Espey MG, Levine M. Vitamin C transporter Slc23a1 links renal reabsorption, vitamin C tissue accumulation, and perinatal survival in mice. J Clin Invest. 2010;120(4):1069-83.

36. Levine M, Wang Y, Padayatty SJ, Morrow J. A new recommended dietary allowance of vitamin C for healthy young women. Proc Natl Acad Sci U S A. 2001;98(17):9842-6.

37. Dhariwal KR, Hartzell WO, Levine M. Ascorbic acid and dehydroascorbic acid measurements in human plasma and serum. Am J Clin Nutr. 1991;54(4):712-6.

38. Chakrabarti B, Banerjee S. Dehydroascorbic acid level in blood of patients suffering from various infectious diseases. Proc Soc Exp Biol Med. 1955:88(4):581-3.

39. Chatterjee $I B$, Banerjee A. Estimation of dehydroascorbic acid in blood of diabetic patients. Anal Biochem. 1979;98(2):368-74.

40. Lunec J, Blake DR. The determination of dehydroascorbic acid and ascorbic acid in the serum and synovial fluid of patients with rheumatoid arthritis (RA). Free Radic Res Commun. 1985:1(1):31-9.

41. Carr AC, Bozonet SM, Pullar JM, Simcock JW, Vissers MC. Human skeletal muscle ascorbate is highly responsive to changes in vitamin C intake and plasma concentrations. Am J Clin Nutr. 2013;97(4):800-7.

42. Vissers MC, Bozonet SM, Pearson JF, Braithwaite LJ. Dietary ascorbate intake affects steady state tissue concentrations in vitamin C-deficient mice: tissue deficiency after suboptimal intake and superior bioavailability from a food source (kiwifruit). Am J Clin Nutr. 2011;93(2):292-301.

43. Lobo SM, Lobo FR, Bota DP, Lopes-Ferreira F, Soliman HM, Melot C, Vincent JL. C-reactive protein levels correlate with mortality and organ failure in critically ill patients. Chest. 2003;123(6):2043-9.

44. Gariballa S, Forster S. Effects of acute-phase response on nutritional status and clinical outcome of hospitalized patients. Nutrition. 2006;22(7-8):750-7.

45. Fowler AA, Syed AA, Knowlson S, Sculthorpe R, Farthing D, DeWilde C, Farthing CA, Larus TL, Martin E, Brophy DF, Gupta S, Fisher BJ, Natarajan R. Phase I safety trial of intravenous ascorbic acid in patients with severe sepsis. J Transl Med. 2014;12:32.

46. Marik PE, Khangoora V, Rivera $\mathrm{R}$, Hooper $\mathrm{MH}$, Catravas J. Hydrocortisone, vitamin $C$ and thiamine for the treatment of severe sepsis and septic shock: a retrospective before-after study. Chest. 2017:151(6):1229-38.

47. Kelly DG. Guidelines and available products for parenteral vitamins and trace elements. JPEN J Parenter Enteral Nutr. 2002;26(5 Suppl):S34-6.

48. Carr AC, Pullar JM, Bozonet SM, Vissers MC. Marginal ascorbate status (hypovitaminosis C) results in an attenuated response to vitamin C supplementation. Nutrients. 2016;8(6):341. 
49. Block G, Mangels AR, Patterson BH, Levander OA, Norkus EP, Taylor PR. Body weight and prior depletion affect plasma ascorbate levels attained on identical vitamin C intake: a controlled-diet study. J Am Coll Nutr. 1999; 18(6):628-37.

50. Fukushima R, Yamazaki E. Vitamin C requirement in surgical patients. Curr Opin Clin Nutr Metab Care. 2010;13(6):669-76.

51. de Grooth HJ, Choo WP, Spoelstra-de Man AM, Swart EL, Oudemans-van Straaten HM. Pharmacokinetics of four high-dose regimes of intravenous vitamin C in critically ill patients [abstract]. Intensive Care Med Exp. 2016;4 Suppl 1:A52.

52. Cossey LN, Rahim F, Larsen CP. Oxalate nephropathy and intravenous vitamin C. Am J Kidney Dis. 2013;61(6):1032-5.

53. Wong K, Thomson C, Bailey RR, McDiarmid S, Gardner J. Acute oxalate nephropathy after a massive intravenous dose of vitamin C. Aust N Z J Med. 1994:24(4):410-1.

54. Lawton JM, Conway LT, Crosson JT, Smith CL, Abraham PA. Acute oxalate nephropathy after massive ascorbic acid administration. Arch Intern Med. 1985;145(5):950-1.

55. Robitaille L, Mamer OA, Miller Jr WH, Levine M, Assouline S, Melnychuk D, Rousseau C, Hoffer L. Oxalic acid excretion after intravenous ascorbic acid administration. Metabolism. 2009;58(2):263-9.

\section{Submit your next manuscript to BioMed Central} and we will help you at every step:

- We accept pre-submission inquiries

- Our selector tool helps you to find the most relevant journal

- We provide round the clock customer support

- Convenient online submission

- Thorough peer review

- Inclusion in PubMed and all major indexing services

- Maximum visibility for your research

Submit your manuscript at www.biomedcentral.com/submit 